\title{
Improving the antimicrobial activity of some probiotics in cereal-based media
} supplemented with growth enhancers

\author{
Kawther El- Shafei, Zeinab I. M. Sadek, Nabil F. Tawfik, Baher A. Effat, Gamal A. \\ Ibrahim, Azzat B. Abd El-Khalek and Osama M. Sharaf
}

Dairy Science Dept. (Dairy Microbiol. Lab.), National Research Centre, 33 El Buhouth St., 12622 Dokki, Giza, Egypt.

Received: 20 July 2020 / Accepted 10 Sept. 2020 / Publication date: 20 Sept. 2020

\begin{abstract}
Recently, consumers have an increasing awareness of their health risks caused by the use of chemicals as food preservatives. In contrast, the growing need by the dairy industry to extend product shelf-life and prevent spoilage of dairy products has a growing necessity for new preservatives and/or new methods of conservation. An attempt was made to develop such kind of probiotic media mixture which can be utilized to increase antimicrobial production. Probiotic media mixes were developed using locally available ingredients such as some cereals extracts (barely, wheat and oat) and supplements as probiotic growth media (Mushroom and yeast powder) and whey, permeate to enhance the production of antibacterial substances against different spoilage and pathogenic bacteria which can be used as fermented media with probiotic or cell-free supernatants. Our results revealed that Lactobacillus reuteri and Lactobacillus curvatus were more antagonistic on the tested pathogens. In case of Lb. curvatus, the inhibitory effect was increased when grown in barely, wheat and oat extracts against the most indicator pathogenic bacteria with variable values. Also, it is clear that mushroom showed more enhancement of antibacterial activity of tested probiotic than yeast extract when supplemented to barley and oats extracts. Generally, the present study confirmed that cereals are suitable substrates for the growth of probiotic bacteria and prepared cheap natural media to improve the production of antimicrobial compounds by probiotics to use as biopreservation in dairy industry for improving the safety of the products.
\end{abstract}

Keywords: Lactobacillus reuteri, Lactobacillus curvatus, Antimicrobial, probiotics, cereals

\section{Introduction}

The preservation of the food by natural and microbiological methods may become satisfactory approach to protect the food products and the consumers from food-borne illness and product spoilage, leading to the increased stability of the food product during its storage and shelf life (Salminen, 1996). So extensive work must be carried out on bacteriocins and bacteriocins like producing strains of Lactic acid bacteria for their potential use on bio preservatives, which improves food safety (Kalkan et al., 2017). Moreover, it can be used as food additive and considered as an inexpensive method for large scale production of cultures containing high levels of viable bacteriocin producers, in a suitable form for product application.

Prebiotics stimulate the probiotic bacteria, it mainly consists of dietary fibers and oligosaccharides and one of its functions is to promote the growth of the beneficial bacteria and discourages the overgrowth at the pathogenic bacteria (Bhakta and Kumar, 2013). The microbial ecosystem beneficial to human health, mainly Bifidobacteria, Lactobacillus species can also be affected by prebiotics which are indigestible but fermentable dietary carbohydrates (Holzapfel and Schillinger, 2002). Researchers concluded that oats are in general suitable substrates for lactic acid bacterial growth regardless of the differences between bacterial species (Marklinder and Lönner, 1992; Gomes and Malcata, 1999). The role of cereals or cereal component as probiotic growth media and carriers has not been fully addressed .Cereals like wheat, maize, rice, oats, ... etc and their ingredients are accepted as functional food and nutraceuticals because of providing dietary fibers, proteins, energy, minerals, vitamins and antioxidants required for human health. Cereals and cereal component-based food offer opportunities to include probiotics, prebiotics and fiber in human. Also,

Corresponding Author: Osama M. Sharaf, Dairy Science Dept. (Dairy Microbiol. Lab.), National Research Centre, 33 El Buhouth St., 12622 Dokki, Giza, Egypt.

E-mail: sharafosama@yahoo.com 
cereals can be used as fermentable substrates for growth of probiotic microorganisms (Charalampopoulos et al., 2002b). Prebiotic effects of arabinoxylan from wheat and B-glucan from barley have been reported (Harris et al., 2019).

Mushrooms seem to be potential source for prebiotics as it is an important source of biological substances with medical value as they contain different polysaccharides such as chitin, hemicelluloses, $\alpha$ and $\beta$-glucans, mannans, xylans and glactones . Mushroom polysaccharides are not only important as prebiotics but they also have antimicrobial, antioxidants and antiviral properties (Hrudayanath and Sameer, 2014). They played an important role in the treatment of various disorders, including infection diseases and therefore some naturally occurring chemical compounds identified in mushrooms serves as models for clinically proven drugs (Smolskait et al., 2015). Also, yeast and its extract contains small peptides and vitamins which can improve the growth of Lactobacilli. Supplementation with yeast to milk medium enhanced both growth and bacteriocin production for probiotic Lactobacillus strains (Avonts et al., 2004). Moreover, Whey and permeate contain factors influencing the growth and metabolic activity leading to the increase of the antibacterial activity of the probiotic strains.

The objective of this research was to study the importance of some cereals extracts and supplements as probiotic growth media to enhance the production of antibacterial substances against different spoilage and pathogenic bacteria which can be used as fermented media with probiotic or cell-free supernatants.

\section{Materials and Methods}

\section{Probiotic strains}

The microorganisms used in the study were as follows: Lactobacillus rhamnosus B-445, Lactobacillus casei B-1922, Lactobacillus Johnosonii B-2198, Lactobacillus reuteri B-1471 and Lactobacillus curvatus B-4562 were provided by Northern Regional Reseach Laboratory, IIIinosis, USA (NRRL).

The probiotic strains were cultured individually in MRS incubated at $37^{\circ} \mathrm{C} / 24 \mathrm{~h}$.

\section{Pathogenic indicator}

Staphylococus aureus, Pseudomonas aeruginosa, Esherichia coli 0157:7 (Dairy microbiology Laboratory), Bacillus cereus B-B711 (NRRL) Listeria monocytogenes Type 1 (Hungarian National Collection of Medical Bacteria, OK1, Budapest. Hungary (HNCMB). They were cultured in tryptone soy broth $37^{\circ} \mathrm{C} / 24 \mathrm{~h}$.

\section{Cereals}

Barely, wheat and oat were purchased from local market in Giza government.

\section{Mushroom and yeast}

Mushroom powder was purchased from Agricultural Research Center . Yeast powder was purchased from local markets.

\section{Permeate and whey}

Permeate and whey was obtained from the Animal Production Research Institute, Agriculture Research Center heat treated before using as a media.

\section{Experimental procedure}

\subsection{Cereal-based fermentation media}

The following method (as described by Chlaralapopoulos et al. (2002a) was used to prepare the cereal fermentation media. The grains (Barely, wheat and oat) were grind in a laboratory falling number hammer mill equipped with $0.5 \mathrm{~mm}$ sieve. The resulting flour $(50 \mathrm{~g})$ was mixed with $450 \mathrm{ml}$ tap water and gently mixed at room temperature for $15 \mathrm{~min}$. This slurry was centrifuged $(6000 \mathrm{~g})$ for $30 \mathrm{~min}$ at room temperature. Then the supernatant fluid was collected and immediately sterilized at $121{ }^{\circ} \mathrm{C}$ for $45 \mathrm{~min}$. Sedimentation of solids was observed after sterilization. The supernatant and sterilization procedures were repeated four times. Probiotic Strains (Lb.casei, Lb. rhamnosus, Lb. 
Johnosonii, Lb. reuteri and Lb. curvatus) were inoculated into resulting cereals extracts at $2 \%(\mathrm{v} / \mathrm{v})$ in $500 \mathrm{ml}$ screw-capped bottles. In all cases, the initial bacterial concentration was approximately $10^{7} \mathrm{cfu}$ $\mathrm{ml}^{-1}$. Fermentation processes are performed at $37^{\circ} \mathrm{C}$ with no $\mathrm{pH}$ control and no agitation MRS broth (Oxoid) was used as a control medium for the same probiotic strains. All fermentations were performed in duplicate.

\subsection{Inhibitory activity against food borne pathogens}

Antibacterial activities of tested probiotic lactic acid bacteria which were inoculated into resulting cereals extracts (Barley, wheat and oat) were assayed using cell-free neutralized supernatants (CFNS) against food borne pathogens by paper disc diffusion assay as described by Mabrouk et al.( 2007). The plates were incubated aerobically at $37^{\circ} \mathrm{C} / 24 \mathrm{~h}$. For screening, the antibacterial activity was evaluated as zones of inhibition (clear zone) LAB with inhibition zones $<5,>5,>8$ and $>10 \mathrm{~mm}$ were classified as + mild; ++ strong; and +++ very strong. The antibacterial effect of the supernatant was evaluated by measurement of the inhibition zone diameter around the discs. Each experiment was performed in three replicates.

\section{Effect of supplementation of yeast and mushroom to the cereals extract media}

\subsection{Preparation of the supplement solution.}

-A stock solution of $10 \%$ of mushroom powder individually was prepared. They were heat treated at $95^{\circ} \mathrm{C}$ for seconds then suddenly cooled.

-Addition of the supplements (solution of mushroom or yeast) with percent $1 \%$ for each cereal extracts (Barely, wheat and oat which were inoculated with Lb. reuteri and Lb. curvatus (2\%) individually.

The inhibition zone was tested after incubation for $48 \mathrm{~h} / 35^{\circ} \mathrm{C}$ as mentioned before.

The treatments were as follows:
1. Barely extract control
6. Wheat extract $+1 \%$ mushroom
2. Barely extract $+1 \%$ yeast
3. Barely extract $+1 \%$ mushroom
4. Wheat extract control
7. Oat extract control
8. Oat extract $+1 \%$ yeast
9. Oat extract $+1 \%$ mushroom.

5. Wheat extract $+1 \%$ yeast

\section{Preparation of natural media for probiotics}

Cereal extracts, mushroom, and some by products as whey and permeate were used .Prepare natural media for probiotics contain barely or oat extract and fermented (or without fermention) whey or permeate as follows:

1- Whey control

2- Fermented whey inoculated with $L$ b. curvatus + cereal extract

3- Fermented whey inoculated with Lb. curvatus + cereal extract $+1 \%$ mushroom.

4- Permeate control

5- Fermented permeate with Lb. curvatus

6- Fermented permeate $49 \%+$ cereal extract $50 \%+1 \%$ mushroom.

All treatments inoculated with pathogenic indicator and incubated for $48 \mathrm{~h} / 35^{\circ} \mathrm{C}$. The pathogenic count in the mixed culture were counted after incubation at intervals in $(0,24$ and $48 \mathrm{~h})$.

\section{Results and Discussion}

\section{Effect of barely, oat and wheat extract on antibacterial activity of tested probiotic strains}

Antibacterial activity of the tested probiotics were screened against Staphylococus aureus, pseudomonas aeruginosa, Esherichia coli, Bacillus cereus, Listeria monocytogenes (Table 1).

Evaluation of the effect of the supplementation of barely, oat and wheat extracts revealed remarkable variability in the obtained results. $L b$. casei grown in barely extract showed more inhibitory effect on Staph. aureus, E. coli and B. cereus as compared with that either grown in oat and 
wheat extract or control (MRS broth, the ordinary media for LAB), while Lb. reuteri showed an inhibitory effect on Staph. aureus, P. aeruginosa and E.coli when grown in barely extract and on E.coli and L. monocytogenes when grown on wheat extract. While, Lb. rhmnosus grown in barely extract was active only against Staph. aureus with no difference could be noticed in wheat or oat than control.

Table 1: Inhibition zone effect of some probiotic Lactobacillus at pathogenic bacteria growth in cereals extract

A. MRS broth

B. Barley extract

\begin{tabular}{|c|c|c|c|c|c|c|c|c|c|c|c|}
\hline Probiotic bacteria & 1 & 2 & 3 & 4 & 5 & Probiotic bacteria & 1 & 2 & 3 & 4 & 5 \\
\hline Lb. johonsonii & + & + & Nil & + & + & Lb. johonsonii & + & ++ & Nil & + & ++ \\
\hline Lb. casei & + & + & Nil & + & + & Lb. casei & ++ & ++ & + & ++ & ++ \\
\hline Lb. rahmnosus & + & + & Nil & + & ++ & Lb. rahmnosus & ++ & + & + & + & + \\
\hline Lb. reuteri & + & + & + & + & + & Lb. reuteri & ++ & ++ & ++ & ++ & + \\
\hline Lb. curvatus & + & + & + & + & + & Lb. curvatus & +++ & ++ & ++ & ++ & ++ \\
\hline
\end{tabular}

C. Wheat extract

D. Oat extract

\begin{tabular}{|c|c|c|c|c|c|c|c|c|c|c|c|}
\hline Probiotic bacteria & 1 & 2 & 3 & 4 & 5 & Probiotic bacteria & 1 & 2 & 3 & 4 & 5 \\
\hline Lb. johonsonii & ++ & + & Nil & + & + & Lb. johonsonii & + & Nil & Nil & ++ & + \\
\hline Lb. casei & + & + & Nil & + & + & Lb. casei & + & + & + & + & + \\
\hline Lb. rahmnosus & + & Nil & + & + & + & L.b. rahmnosus & + & Nil & Nil & + & ++ \\
\hline Lb. reuteri & + & + & ++ & +++ & +++ & Lb. reuteri & + & + & + & ++ & ++ \\
\hline Lb. curvatus & ++ & + & + & ++ & ++ & Lb. curvatus & ++ & ++ & +++ & ++ & \\
\hline
\end{tabular}

Pathogenic bacteria: 1- Staph. aureus, 2-B.cereus, 3- Pseudomonas aeruginosa, 4- Esherichia coli, 5-Listeria monocytogenes, Nil : No Inhibition, $0.2-0.3(+), 0.3-0.5(++),<0.5(+++)$

So, the pattern of the inhibition the pathogenic bacteria represented that $L b$. reuteri and $L b$. curvatus were more antagonistic most the tested pathogen with different in size of inhibition zone.

In case of Lb. curvatus, the inhibitory effect was increased when grown in barely, wheat and oat extracts against the most indicator pathogenic bacteria with variable values.

The antimicrobial activity of probiotics have been reported (Alakomi et al., 2000, Avonts et al., 2004, Røssland et al., 2005). Probiotics have been used to prevent some intestine pathogenic infections such as Salmonella Shigella, E. coli, Listeria (Ghalfi et al., 2006). Also, antimicrobial proteinaceus compounds such as bacteriocins or bacteriocin-like compounds produced by probiotic bacteria have been found to have potent antimicrobial activities towards undesirable harmful microoraginsms. Also, these, results are in agreement with the literature data and scientific reports mentioned that bacteriocins of lactic acid bacteria have a good spectrum activity against pathogens and food spoilage bacteria (Mabrouk et al., 2020.; Castro et al., 2011; Todorov and Dicks, 2009; Cizeikiene et al., 2013).

Generally, malt, wheat and barely extracts exhibited a good factor for increasing inhibitory activity of the tested probiotics strains toward the tested pathogenic organisms. Compared with MRS media, cereals like wheat, buckwheat, oat and barley are suitable for the growth of potentially probiotic lactic acid bacteria (Charalampopoulos et al., 2002b). Also, Ötles and Cagindi (2006) reported that cereals can be used as fermentable substrates for growth of probiotic microorganisms. So, leading to increased production of probiotic bacterial mass and increasing the antibacterial activity as a result $L b$. reuteri and $L b$. curvatus which show more inhibitory effects with theses extracts were chosen to continue studies with other additives for more increasing of the antibacterial effect by adding supplements as yeast and mushroom powder.

\section{Effect of yeast and mushroom powder on antibacterial production of tested probiotic strains}

The results obtained in Table 2 indicates that supplementation of mushroom powder and yeast (1\%) enhanced the antibacterial activity of the tested probiotics compared by control. Addition of $1 \%$ yeast extract to milk medium led to highest cell numbers of Lb. johnsonii and Lb. gasseri during 
growth (Avonts et al., 2004). Also, it is known that many antioxidant active compounds may also possess different effects against microorganisms (Smolskait et al., 2015).

Table 2: Effect of cereal extracts with yeast or mushroom fermented by probiotics on pathogenic bacteria

\begin{tabular}{|c|c|c|c|c|c|c|}
\hline \multirow{10}{*}{ 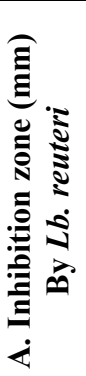 } & Treatments & 1 & 2 & 3 & 4 & 5 \\
\hline & Barley extract control & 1.0 & 0.5 & 0.5 & 0.5 & 0.5 \\
\hline & Barley extract (+1\%yeast) & 1.0 & 0.5 & 0.5 & 0.7 & 0.7 \\
\hline & Barley extract $(+1 \%$ mashroum) & 1.0 & 0.5 & 1.1 & 0.9 & 0.7 \\
\hline & Wheat extract control & 0.7 & 0.5 & 0.5 & 0.7 & 0.3 \\
\hline & Wheat extract (+1\%yeast) & 1.3 & 0.5 & 0.5 & 1.0 & 0.3 \\
\hline & Wheat extract (+1\% mashroum) & 1.3 & 0.5 & 0.5 & 1.0 & 0.3 \\
\hline & Oat extract control & 0.5 & 0.5 & 0.5 & 0.6 & 0.7 \\
\hline & Oat extract (+1\%yeast) & 0.5 & 0.5 & 0.5 & 1.2 & 0.8 \\
\hline & Oat extract $(+1 \%$ mashroum $)$ & 0.5 & 0.5 & 0.5 & 1.3 & 0.8 \\
\hline \multirow{10}{*}{ 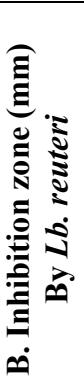 } & Treatments & 1 & 2 & 3 & 4 & 5 \\
\hline & Barley extract control & 0.5 & 0.5 & 0.7 & 0.7 & 0.7 \\
\hline & Barley extract (+1\%yeast) & 0.7 & 1.5 & 1.2 & 1.4 & 0.7 \\
\hline & Barley extract $(+1 \%$ mashroum $)$ & 0.7 & 1.5 & 1.5 & 1.4 & 1.0 \\
\hline & Wheat extract control & 0.7 & 1.2 & 0.5 & 0.5 & 0.5 \\
\hline & Wheat extract (+1\%yeast) & 1.1 & 1.2 & 0.7 & 1.1 & 0.5 \\
\hline & Wheat extract $(+1 \%$ mashroum $)$ & 1.1 & 1.5 & 1.4 & 1.1 & 1.0 \\
\hline & Oat extract control & 1.0 & 0.7 & 1.0 & 0.7 & 0.5 \\
\hline & Oat extract (+1\%yeast) & 2.2 & 0.9 & 1.2 & 1.8 & 0.7 \\
\hline & Oat extract $(+1 \%$ mashroum $)$ & 2.2 & 2.2 & 1.5 & 1.9 & 1.2 \\
\hline
\end{tabular}

1-Staph.aureus, 2-B.cereus, 3- Pseudomonas aeruginosa, 4- Esherichia coli, 5- Listeria monocytogenes

Also, it is clear that mushroom showed more enhancement of antibacterial activity of tested probiotic ( $L b$. reuteri and Lb. curvatus) than yeast extract when supplemented to barley and oats extracts when added as powder (1\%). On the other hand, Lb. curvatus proved to be more affected for the antibacterial activity by growing in $1 \%$ mushroom powder than $L b$. reuteri. The increase of the probiotics activity may be due to the richness of many nutrients which lead to the increase in probiotic growth. The richness in carbohydrates, proteins, fibers, vitamins, minerals, the presence of the unsaturated fatty acids and bioactive compounds (e.g. phenolic compounds and tocopherols) in some kinds of mushroom (Heleno et al., 2015). Moreover, mushrooms played an important role in the treatment of various disorders, including infectious diseases and therefore some naturally occurring chemical compounds identified in mushrooms served as models for clinically proved drugs. Moreover, mushroom polysaccharides are not only important as prebiotics but have immense biological properties such as antitumor, antimicrobial antioxidant and antiviral (Barros et al., 2008).

According to the results of mixed cultures assay, Lb. curvatus confirmed to be more inhibitory than other tested probiotics toward the pathogenic indicator especially.

Additionally, mushroom solution $1 \%$ enhance the inhibitory activity than yeast solution did. Barely and mushroom were chosen for Lb.curvatus to continue with the oat and prepataed natural media.

3. Prepare natural supplemented media with Barely extract, Oat, fermented or without fermentation whey or permeate and mushroom for increase $L b$. curvatus activity.

Whey and permeate were by-products of the cheese industry disposed as waste whey which is a source of biological and functional valuable proteins (Pescuma et al., 2008).

Oat and barely media was significally changed during ferementation. The fermentation process via specific strains of bacteria makes the whey more functional because the production of bioactive peptides during fermentation (Mazorra-Manzano, 2020).

Antagonism activity of the supplemented media with barley, fermented or non-fermented permeate, whey and mushroom towards tested pathogenic are presented in Fig (1). 


\section{E. coli}

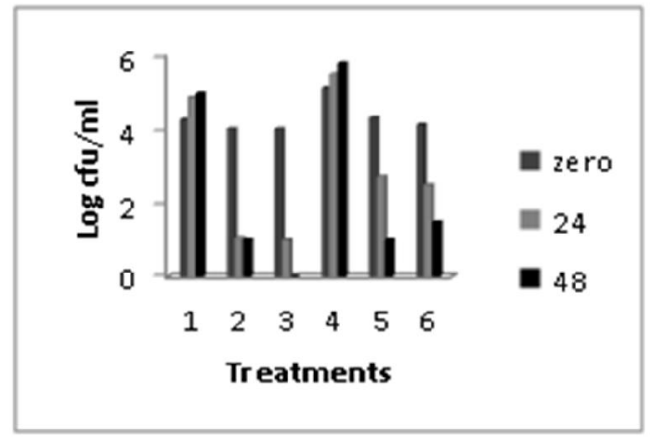

Pseudomonas aeruginosa

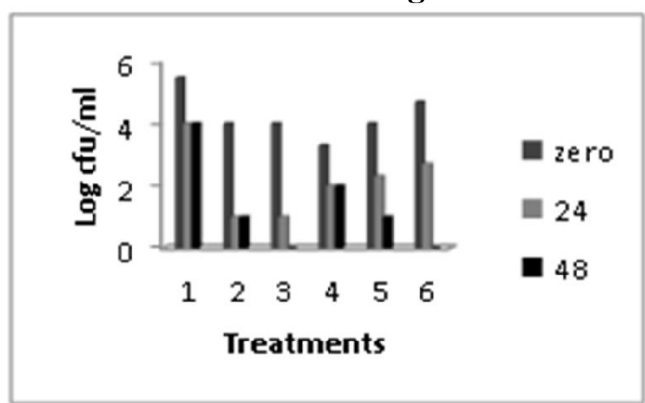

Bacillus cereus

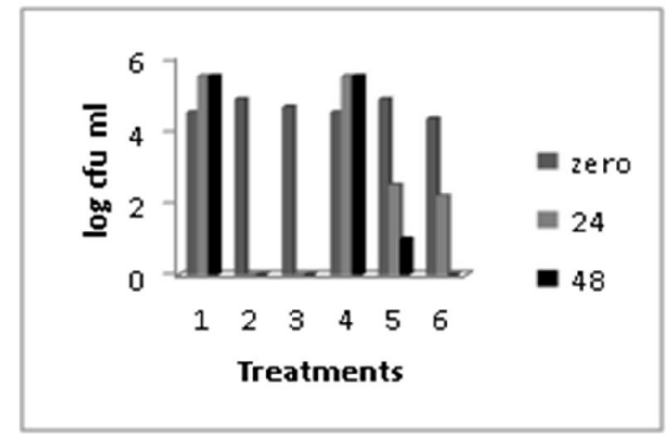

Listeria monocytogenes

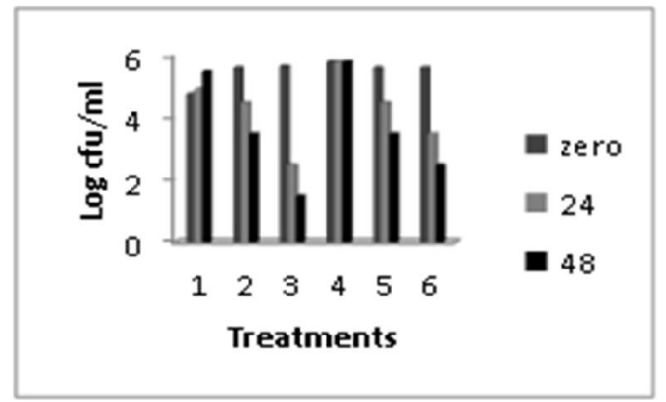

Staph. aureus

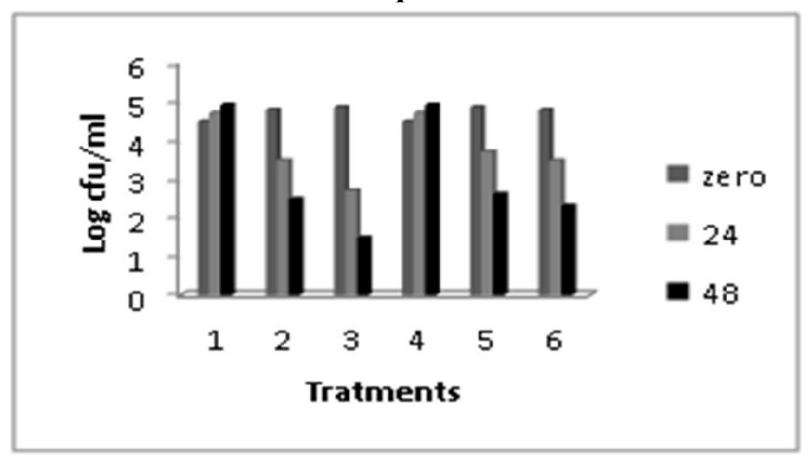

Fig. 1: Effect of Barley extract with some supplement fermented by Lb curvatus on survival of pathogenic bacteria

\section{Whey control.}

Fermented whey inoculated with $L$. curvatus + oat extract.

Fermented whey $49 \%$ inoculated with $L$. curvatus + oat extract $50 \%+1 \%$ mushroom.

Permiate control.

Fermented permeate with L. curvatus + oat extract.

6 Fermented permeate $49 \%$ + oat extract $50 \%+1 \%$ mushroom. 


\section{E. coli}

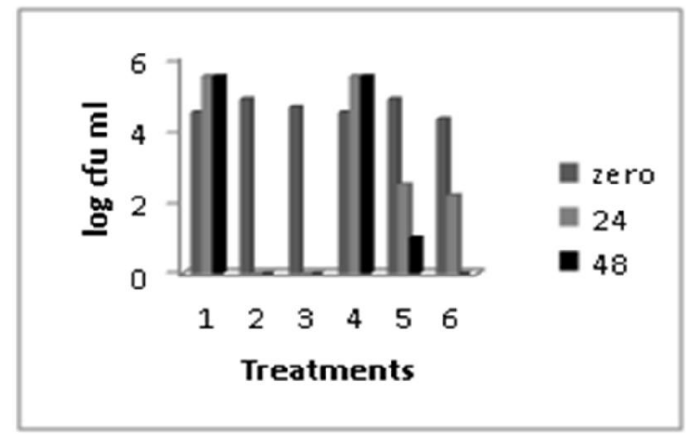

Pseudomonas aeruginosa

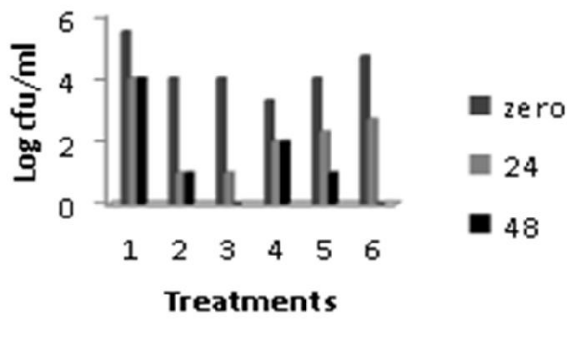

Bacillus cereus

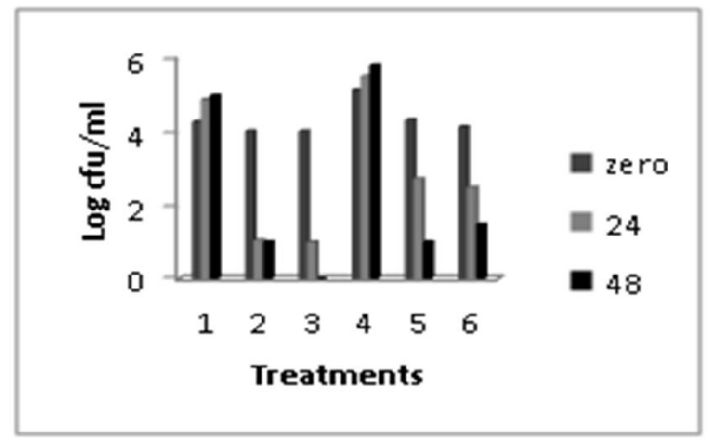

Listeria monocytogenes

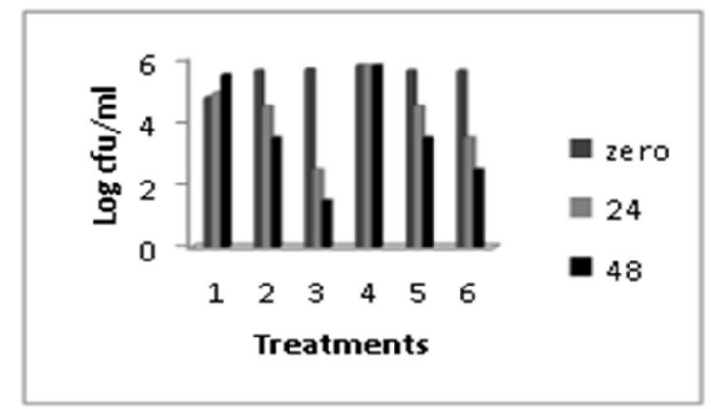

Staph. aureus

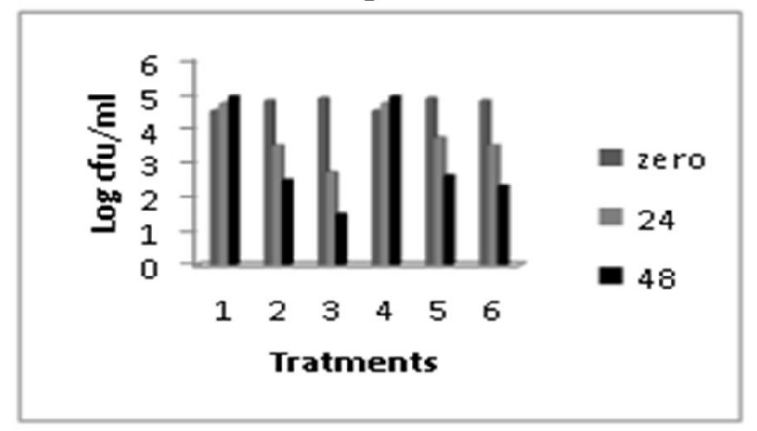

Fig. 2: Effect of oat extract with some supplement fermented by Lb. curvatus on survival of pathogenic bacteria.

1 Whey control.

2 Fermented whey inoculated with L. curvatus +oat extract.

3 Fermented whey49\% inoculated with L. curvatus + oat extract $50 \%+1 \%$ mushroom.

4 Permiate control.

5 Fermented permeate with L. curvatus + oat extract

6 Fermented permeate $49 \%+$ oat extract $50 \%+1 \%$ mushroom.

The numbers of $E$. coli reached cell count above $5 \log \mathrm{cfu} / \mathrm{ml}$ after 24 and $48 \mathrm{~h}$ in control (whey only) and (permeate control) while in fermented permeate, E. coli decreased after 24 and $48 \mathrm{~h}$ the decrease reached $3 \log$ cycles and when fermented permeate was supplemented with mushroom, numbers of $E$. coli decreased by about $2 \log$ cycle after $24 \mathrm{~h}$ and disappeared after $48 \mathrm{~h}$.

Generally supplementation of fermented whey with mushroom led to decrease in the number of E. coli in whey or permeate when supplement in oat extract (Fig 2). The lentian which is polysaccharides like glucan in mushroom inhibits Salmonella . 
Nearly, similar behavior with barely extract, but fermentation of permeate with mushroom increased the antibacterial activity of Lb. curvatus in barely extract (Fig 1). Also, fermentation of barely extract with permeate and supplemented with mushroom showed higher antibacterial activity than permeate only (Fig 1). While the opposite was observed for fermented oat extract supplemented with whey and mushroom which gave best results against $B$ cereus which disappeared after $48 \mathrm{~h}$. Nevertheless, all the tested treatments revealed antimicrobial activity compared with control, it may be observed that $P$. aeruginosa, Staph.aureus, L.monocytogenes were most susceptible bacteria to oat or barley extracts with or without mushroom showed higher antibacterial activity towards $P$. aerginosa than other treatments. Oats are, in general, suitable substrates for LAB growth, regardless of differences between bacterial species (Marklinder and Lönner, 1992).

Oat, wheat and barely extracts exhibited protective effect on the tested probiotic strains this may be attributed to the presence of non-digestible component of the cereal matrix which may also serve as prebiotics (Charalampopoulos et al., 2002b). Moreover, Reavthy et al., (2011) reported barely as prebiotic served as best substrate for the growth of Lactobacillus spp.

Generally, cereals are suitable substrates for the growth of potentially probiotic lactic acid bacteria (Charalampopoulos et al., 2002a). Also, results of Patel et al., (2004) indicated that malt wheat and barley extracts were able to exhibit a significant protective effect on the viability of lactobacilli, this effect was mainly attributable to the amount of carbohydrates present in the cereals.

\section{Conclusion}

Conclusively, it was found out that Lactobacillus reuteri and Lactobacillus curvatus showed the highest antagonistic activity against the tested pathogens and suitability of cereal- based media as a viable delivery vehicle for probiotics. In particular, there were increments the variety of antimicrobial compounds activity of the fermented product. So, we could prepare cheap natural media to improve the growth and the production of antibacterial compounds by probiotics to use the compounds like bacteriocin and bacteriocin-like to use as biopreservation in dairy industry for improving the safety of the products.

\section{Acknowledgement}

Allah have grace, and forgive for Prof Dr. Moussa M.A. Salem, Who participated in the search and died before the work ended.Thanks my friend Dr Moussa

\section{References}

Alakomi, H. L., E. Skyttä, M. Saarela, T. Mattila-Sandholm, K. Latva-Kala, and I. M. Helander. 2000. Lactic acid permeabilizes gram-negative bacteria by disrupting the outer membrane. Applied and Environmental Microbiology, 66 (5): 2001-5. https://doi.org/10.1128/AEM.66.5.2001-2005.2000.

Avonts, L., V.U. Erika, and D.V. Luc 2004. Cell growth and bacteriocin production of probiotic lactobacillus strains in different media. International Dairy Journal 14 (11): 947-55. https://doi.org/10.1016/j.idairyj.2004.04.003.

Barros, L., C.Telma, B. Paula, Letícia M. Estevinho, and Isabel C.F.R. Ferreira. 2008. Wild and commercial mushrooms as source of nutrients and nutraceuticals. Food and Chemical Toxicology, 46 (8): 2742-47. https://doi.org/10.1016/j.fct.2008.04.030.

Bhakta, M., and K. Prasant 2013. Mushroom polysaccharides as a potential prebiotics. International Journal of Health Sciences \& Research (www.Ijhsr.Org) 3 (8): 77. www.ijhsr.org.

Castro, M.P., N.Z. Palavecino, C. Herman, O.A. Garro, and C.A. Campos. 2011. Lactic acid bacteria isolated from artisanal dry sausages: characterization of antibacterial compounds and study of the factors affecting bacteriocin production. Meat Science, 87 (4): 321-29. https://doi.org/10.1016/j.meatsci.2010.11.006.

Charalampopoulos, D., S.S. Pandiella, and C. Webb, 2002 a. Growth Studies of potentially probiotic lactic acid bacteria in cereal-based substrates. Journal of Applied Microbiology, 92(5): 851-59. https://doi.org/10.1046/j.1365-2672.2002.01592.x.

Charalampopoulos, D., R. Wang, S. Pandiella, and C. Webb, 2002b. Application of cereals and cereal 
components in functional foods: A Review. International Journal of Food Microbiology 79 (12): 131-41. https://doi.org/10.1016/S0168-1605(02)00187-3.

Cizeikiene, D., J. Grazina, P. Algimantas, and B. Elena, 2013. Antimicrobial activity of lactic acid bacteria against pathogenic and spoilage microorganism isolated from food and their control in wheat bread. Food Control, 31 (2): 539-45. https://doi.org/10.1016/j.foodcont.2012.12.004.

Ghalfi, H., A. Allaoui, J. Destain, N. Benkerroum, and P. Thonart, 2006. Bacteriocin activity by lactobacillus curvatus cwbi-b28 to inactivate listeria monocytogenes in cold-smoked salmon during $4^{\circ} \mathrm{c}$ storage. Journal of Food Protection, 69 (5): 1066-71.

https://doi.org/10.4315/0362-028X-69.5.1066.

Gomes, Ana M.P., and F. Xavier Malcata, 1999. Bifidobacterium Spp. and lactobacillus acidophilus: biological, biochemical, technological and therapeutical properties relevant for use as probiotics. Trends in Food Science and Technology 10 (4-5): 139-57. https://doi.org/10.1016/S0924-2244(99)00033-3.

Harris S, A. Monteagudo-Mera, O. Kosik, D. Charalampopoulos, P. Shewry, and A. Lovegrove, 2019. Comparative prebiotic activity of mixtures of cereal grain polysaccharides. AMB Expr. 9:203

Heleno, S.A., B. Lillian, M. Anabela, M. Patricia, F.-R. Virginia, G. Jasmina, S. Marina, and Isabel C.F.R. Ferreira, 2015.Nutritional value, bioactive compounds, antimicrobial activity and bioaccessibility studies with wild edible mushrooms. LWT - Food Science and Technology 63 (2): 799-806. https://doi.org/10.1016/j.1wt.2015.04.028.

Holzapfel, W.H., and S. Ulrich, 2002. Introduction to Pre- and Probiotics. In Food Research International, 35:109-16. Elsevier. https://doi.org/10.1016/S0963-9969(01)00171-5.

Hrudayanath, T., and S.S. Kumar, 2014. Diversity, nutritional composition and medicinal potential of indian mushrooms: A Review. African Journal of Biotechnology 13 (4): 523-45. https://doi.org/10.5897/ajb2013.13446.

Kalkan, S., T. Elçin, E. Zerrin, and Ü.T. Emel, 2017. Determination of antimicrobial effects of probiotic lactic acid bacteria and garlic extract against some foodborn pathogenic bacteria. Turkish Journal of Agriculture - Food Science and Technology 5 (2): 125. https://doi.org/10.24925/turjaf.v5i2.125-131.965.

Mabrouk, A. M. M., B.A.M. Effat, , Z.I.M. Sadek, , G. A. Hussein, and M. N. I. Magdoub, 2007. Probiotic properties of some Lactobacillus strains. International Journal of Probiotics and Prebiotics, 2 (4): 175 - 184.

Mabrouk, A.M.M., A.M.E. Baher, Zainab I.M. Sadek, N.F. Tawfiek, Z.M.R. Hassan, and N.I.M. Mohamed, 2020 Antibacterial activity of some lactic acid bacteria isolated from Egyptian dairy products. International Journal of ChemTech Research CODEN. Vol. 6. Accessed April 5, 2020. http://www.sphinxsai.com/framesphinxsaichemtech.htm.

Marklinder, I., and C. Lönner. 1992. Fermentation properties of intestinal strains of lactobacillus, of a sour dough and of a yoghurt starter culture in an oat-based nutritive solution. Food Microbiology 9 (3): 197-205. https://doi.org/10.1016/0740-0020(92)80047-8.

Mazorra-Manzano, M., G. Robles-Porchas, A.G.V. Daniel, J.T.-L. María, M.P. Marcel, Celia O. García-Sifuentes, F.G.-C. Aarón and V.-C. Belinda, 2020. Cheese whey fermentation by its native microbiota: proteolysis and bioactive peptides release with ACE-inhibitory activity. Fermentation, 6(1): 19.

Ötles, S., and C. Özlem, 2006. cereal based functional foods and nutraceuticals. ACTA Acta Sci. Pol., Technol. Aliment., Vol. 5.

Pescuma, M., M.H. Elvira, M. Fernanda, and F.V. Graciela, 2008. Whey fermentation by thermophilic lactic acid bacteria: evolution of carbohydrates and protein content. Food Microbiology, 25 (3): 442-51. https://doi.org/10.1016/j.fm.2008.01.007.

Revathy, T., S. Mythili, and A. Sathiavelu, 2011. Assessing the growth of probiotic bacteria in selected prebiotic foods rich in oligosaccharides. International Journal of Applied Biology and Pharmaceutical Technology, 2(1): 483-487.

Patel, H.M., S.S. Pandiella, R.H. Wang, and W. Colin, 2004. Influence of malt, wheat, and barley extracts on the bile tolerance of selected strains of lactobacilli. Food Microbiology 21(1): 83-89. DOI: $10.1016 / \mathrm{S} 0740-0020(03) 00016-9$

Røssland, E., L. Thor, G. Per Einar, and S. Terje 2005. Production of antimicrobial metabolites by 
strains of lactobacillus or lactococcus co-cultured with bacillus cereus in milk. International Journal of Food Microbiology, 98 (2): 193-200. https://doi.org/10.1016/j.ijfoodmicro.2004.06.003.

Salminen, S., 1996. Clinical uses of probiotics for stabilizing the gut mucosal barrier: successful strains and future challenges. Antonie van Leeuwenhoek, International Journal of General and Molecular Microbiology. Springer. https://doi.org/10.1007/BF00395941.

Smolskait, L., R.V. Petras, and T.Thierry, 2015. Comprehensive evaluation of antioxidant and antimicrobial properties of different mushroom species. LWT - Food Science and Technology 60 (1): 462-71. https://doi.org/10.1016/j.lwt.2014.08.007.

Todorov, S.D., and Leon M.T. Dicks, 2009. Bacteriocin Production by Pediococcus pentosaceus isolated from marula (scerocarya birrea). International Journal of Food Microbiology, 132 (23): 117-26. https://doi.org/10.1016/j.ijfoodmicro.2009.04.010. 